\title{
UV and infrared absorption spectra, atmospheric lifetimes, and ozone depletion and global warming potentials for $\mathrm{CCl}_{2} \mathrm{FCCl}_{2} \mathbf{F}$ (CFC-112), $\mathrm{CCl}_{3} \mathrm{CClF}_{2}$ (CFC-112a), $\mathrm{CCl}_{3} \mathrm{CF}_{3}$ (CFC-113a), and $\mathrm{CCl}_{2} \mathrm{FCF}_{3}$ (CFC-114a)
}

\author{
Maxine E. Davis ${ }^{1,2,3}$, François Bernard ${ }^{1,2}$, Max R. McGillen ${ }^{1,2}$, Eric L. Fleming ${ }^{4,5}$, and James B. Burkholder ${ }^{1}$ \\ ${ }^{1}$ Earth System Research Laboratory, Chemical Sciences Division, National Oceanic and Atmospheric Administration, \\ Boulder, Colorado, USA \\ ${ }^{2}$ Cooperative Institute for Research in Environmental Sciences, University of Colorado, Boulder, Colorado, USA \\ ${ }^{3}$ Michigan State University, Lyman Briggs College, East Lansing, Michigan, USA \\ ${ }^{4}$ NASA Goddard Space Flight Center, Greenbelt, Maryland, USA \\ ${ }^{5}$ Science Systems and Applications, Inc., Lanham, Maryland, USA
}

Correspondence to: James B. Burkholder (james.b.burkholder@noaa.gov)

Received: 29 February 2016 - Published in Atmos. Chem. Phys. Discuss.: 7 March 2016

Revised: 31 May 2016 - Accepted: 11 June 2016 - Published: 1 July 2016

\begin{abstract}
The potential impact of $\mathrm{CCl}_{2} \mathrm{FCF}_{3}$ (CFC$114 \mathrm{a}$ ) and the recently observed $\mathrm{CCl}_{2} \mathrm{FCCl}_{2} \mathrm{~F}$ (CFC-112), $\mathrm{CCl}_{3} \mathrm{CClF}_{2}$ (CFC-112a), and $\mathrm{CCl}_{3} \mathrm{CF}_{3}$ (CFC-113a) chlorofluorocarbons (CFCs) on stratospheric ozone and climate is presently not well characterized. In this study, the UV absorption spectra of these CFCs were measured between 192.5 and $235 \mathrm{~nm}$ over the temperature range $207-323 \mathrm{~K}$. Precise parameterizations of the UV absorption spectra are presented. A 2-D atmospheric model was used to evaluate the CFC atmospheric loss processes, lifetimes, ozone depletion potentials (ODPs), and the associated uncertainty ranges in these metrics due to the kinetic and photochemical uncertainty. The CFCs are primarily removed in the stratosphere by short-wavelength UV photolysis with calculated global annually averaged steady-state lifetimes (years) of 63.6 (61.9-64.7), 51.5 (50.0-52.6), 55.4 (54.3-56.3), and 105.3 (102.9-107.4) for CFC-112, CFC-112a, CFC-113a, and $\mathrm{CFC}-114 \mathrm{a}$, respectively. The range of lifetimes given in parentheses is due to the $2 \sigma$ uncertainty in the UV absorption spectra and $\mathrm{O}\left({ }^{1} \mathrm{D}\right)$ rate coefficients included in the model calculations. The 2-D model was also used to calculate the CFC ozone depletion potentials (ODPs) with values of 0.98, 0.86, 0.73, and 0.72 obtained for CFC-112, CFC-112a, CFC-113a, and CFC-114a, respectively. Using the infrared absorption spectra and lifetimes determined in this work, the
\end{abstract}

CFC global warming potentials (GWPs) were estimated to be 4260 (CFC-112), 3330 (CFC-112a), 3650 (CFC-113a), and 6510 (CFC-114a) for the 100-year time horizon.

\section{Introduction}

Chlorofluorocarbons (CFCs) are potent ozone-depleting and greenhouse gases that were phased out of production under the Montreal Protocol agreement (1987) and its subsequent amendments and adjustments. Laube et al. (2014) recently reported the first observation of tetrachloro-1,2difluoroethane $\left(\mathrm{CCl}_{2} \mathrm{FCCl}_{2} \mathrm{~F}, \mathrm{CFC}-112\right)$, tetrachloro-1,1difluoroethane $\left(\mathrm{CCl}_{3} \mathrm{CClF}_{2}, \mathrm{CFC}-112 \mathrm{a}\right)$, and 1,1,1-trichloro2,2,2-trifluoroethane $\left(\mathrm{CCl}_{3} \mathrm{CF}_{3}, \mathrm{CFC}-113 \mathrm{a}\right)$ in the atmosphere with emission sources dating back to the 1960s. The atmospheric mixing ratios in the year 2000 were found to be $\sim 0.5$ ppt (parts per trillion) (CFC-112), $\sim 0.08$ ppt (CFC$112 \mathrm{a})$, and $\sim 0.3 \mathrm{ppt}$ (CFC-113a), which are minor compared to a total chlorine mixing ratio of $3.3 \mathrm{ppb}$ (parts per billion) (year 2012), where $\mathrm{CCl}_{3} \mathrm{~F}$ (CFC-11), $\mathrm{CCl}_{2} \mathrm{~F}_{2}$ (CFC12 ), and $\mathrm{CCl}_{2} \mathrm{FCClF}_{2}$ (CFC-113) account for $\sim 60 \%$ of the total (WMO, 2014). The atmospheric mixing ratio of CFC112 and CFC-112a was found to have leveled off in the late 
1990s, while the mixing ratio of CFC-113a was found to be increasing through to the present day, which is contrary to the objectives of the Montreal Protocol. Laube et al. (2014) estimated the stratospheric lifetimes for these substances, using a tracer-tracer analysis, to be 51 (37-82), 44 (28-98), and 51 (27-264) years for CFC-112, CFC-112a, and CFC-113a, respectively, where the values in parentheses are the range of the lifetimes determined in their analysis. The inferred ozone depletion potentials (ODPs) were $0.88(0.62-1.44), 0.88$ (0.5-2.19), and 0.68 (0.34-3.79) for CFC-112, CFC-112a, and CFC-113a, respectively, where the range in parentheses was derived from the range in the $\mathrm{CFC}$ lifetime given above. Atmospheric measurements of CFC-114 are estimated to include a $\sim 10 \%$ fraction due to CFC-114a (WMO, 2014). The atmospheric lifetime of CFC-114a is estimated to be similar to that of CFC-12, i.e., $\sim 100$ years (WMO, 2014). It is clear that the CFCs are long-lived compounds and potent ozonedepleting substances and greenhouse gases. It is expected that these compounds would be predominantly removed from the atmosphere via short-wavelength UV photolysis, primarily in the stratosphere. However, to date, there are no UV absorption spectra for these compounds available, which are needed to better evaluate their atmospheric impact.

In this study, UV absorption spectra were measured for CFC-112, CFC-112a, CFC-113a, and 1,1dichlorotetrafluoroethane $\left(\mathrm{CCl}_{2} \mathrm{FCF}_{3}, \mathrm{CFC}-114 \mathrm{a}\right)$ between 192.5 and $235 \mathrm{~nm}$ over the temperature range $207-323 \mathrm{~K}$. The Goddard Space Flight Center (GSFC) 2-D atmospheric model was used to evaluate the reactive and photolytic loss processes and calculate globally averaged lifetimes and ozone depletion potentials. In addition, infrared absorption spectra were measured at $296 \mathrm{~K}$ for these compounds and used to estimate their global warming potentials (GWPs). The present results are compared with results from the previous infrared studies of Olliff and Fischer $(1992,1994)$ (CFCs 112, 112a, 113a, and 114a) and Etminan et al. (2014) (CFC113a).

\section{Experimental details}

\subsection{UV measurements}

The experimental apparatus has been described in detail previously (McGillen et al., 2013; Papadimitriou et al., 2013a, b) and is only briefly discussed here. The output of a stable $30 \mathrm{~W}$ deuterium $\left(\mathrm{D}_{2}\right)$ lamp light source was collimated and directed through a jacketed $90.4 \pm 0.3 \mathrm{~cm}$ single-pass absorption cell. The beam exiting the cell was focused onto the entrance slit $(150 \mu \mathrm{m})$ of a $0.25 \mathrm{~m}$ monochromator $(\sim 1 \mathrm{~nm}$ resolution) and detected using a photomultiplier tube (PMT). The temperature of the absorption cell was controlled to within $\pm 1 \mathrm{~K}$. Absorption measurements were made at 10 discrete wavelengths at temperatures between 207 and $323 \mathrm{~K}$ to enable spectrum parameterizations appropriate for stratospheric conditions.

Beer's law was applied to determine the absorption cross section, $\sigma(\lambda, T)$, at each wavelength and temperature:

$A(\lambda, T)=\ln \left[\frac{I_{0}(\lambda)-I_{d}}{I(\lambda)-I_{d}}\right]=\sigma(\lambda, T) \times L \times[\mathrm{CFC}]$,

where $A(\lambda, T)$ is the absorbance at wavelength $\lambda$ and temperature $\mathrm{T}, I_{d}$ is the signal recorded in the absence of light, $I_{0}(\lambda)$ and $I(\lambda)$ are the measured signal in the absence and presence of the CFC sample, $L$ is the cell pathlength, and $[C F C]$ is the gas-phase $\mathrm{CFC}$ concentration. The PMT signal was recorded with a $1 \mathrm{kHz}$ sampling rate and a $\sim 20 \mathrm{~s}$ average was used in the data analysis. $I_{0}(\lambda)$ was recorded at the beginning and end of each measurement, which typically agreed to $0.1 \%$ or better. Absorbance measurements were made at each wavelength over a range of CFC concentration under static conditions. The CFCs were added to the absorption cell from dilute mixtures; the CFC concentration was determined using the sample mixing ratio, the absorption cell pressure and temperature, and the ideal gas law. A linear least-squares fit of $A(\lambda, T)$ vs. [CFC] was used to obtain $\sigma(\lambda, T)$.

For the CFC-112 and CFC-112a measurements, an optical neutral density filter was inserted between the $\mathrm{D}_{2}$ lamp and the absorption cell to attenuate the probe beam and minimize CFC loss due to photolysis (sample photolysis was not observed for CFC-113a and CFC-114a). In addition, a mechanical shutter blocked the $\mathrm{D}_{2}$ lamp beam while the absorption cell was being filled. Under most conditions, photolytic loss of the CFC-112 and CFC-112a was undetectable. However, at the higher concentrations used in this study minor photolytic loss $(<2 \%)$ was observed. In these cases, a leastsquares fit of the first $\sim 20 \mathrm{~s}$ of the PMT signal was used in the data analysis to obtain the initial $I(\lambda)$ signal.

\subsection{Infrared absorption measurements}

Infrared absorption spectra at $296 \mathrm{~K}$ for CFC-112, CFC112a, CFC-113a, and CFC-114a were measured over the 500 to $4000 \mathrm{~cm}^{-1}$ wavenumber range using Fourier transform infrared (FTIR) spectroscopy. Measurements were made using a $15 \mathrm{~cm}$ single-pass Pyrex absorption cell and an MCT detector at a resolution of $1 \mathrm{~cm}^{-1}$ with 100 co-adds. The CFC sample was introduced into the absorption cell from a dilute mixture prepared offline, and the CFC concentration was determined using the ideal gas law. Absorption cross sections were determined using Beer's law, Eq. (1), with the spectrum measurements consisting of $\sim 10$ different concentrations. The concentration ranges used were (in $10^{16}$ molecule $\mathrm{cm}^{-3}$ ) (0.348-10.2), (0.453-3.84), (0.376-1.90), and (0.279-4.02) for CFC-112, CFC-112a, CFC-113a, and CFC-114a, respectively. The infrared absorption spectra recorded for CFC112 and CFC-112a were corrected for the presence of a minor $(\sim 4 \%)$ isomer impurity as determined from a ${ }^{19} \mathrm{~F} \mathrm{NMR}$ sample analysis. 


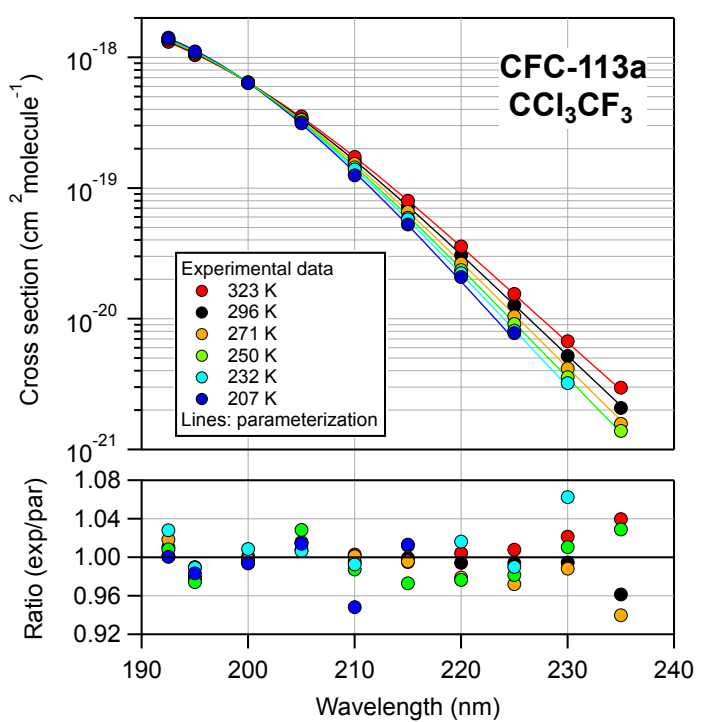

Figure 1. $\mathrm{CCl}_{3} \mathrm{CF}_{3}$ (CFC-113a) UV absorption spectrum (base e) and parameterization obtained in this work. Cross section data (symbols, Table 1) and the parameterization of the data using the empirical formula and parameters given in Table 3 (see text). The lower frame shows the overall quality of the parameterization.

\subsection{Materials}

Samples of $\mathrm{CCl}_{2} \mathrm{FCCl}_{2} \mathrm{~F}$ (CFC-112, $97 \%$ stated purity), $\mathrm{CCl}_{3} \mathrm{CClF}_{2}$ (CFC-112a, $96 \%$ stated purity), $\mathrm{CCl}_{3} \mathrm{CF}_{3}$ (CFC$113 \mathrm{a}, 99 \%$ stated purity), and $\mathrm{CCl}_{2} \mathrm{FCF}_{3}$ (CFC-114a, $99.9 \%$ stated purity) were obtained commercially. The samples were processed in several freeze $(77 \mathrm{~K})$-pump-thaw cycles prior to use. The CFC-114a sample was also treated with freeze (197 K)-pump-thaw cycles to remove $\mathrm{CO}_{2}$ from the sample. The liquid CFC-112, CFC-112a, and CFC-113a samples were stored under vacuum in Pyrex reservoirs. The CFC-112 and CFC-112a samples contained minor isomeric impurities, which were quantified using ${ }^{19} \mathrm{FNMR}$ to be 0.960/0.040 (CFC-112a/CFC-112) for the CFC-112a sample and $0.963 / 0.0368$ (CFC-112/CFC-112a) for the CFC112 sample. Dilute mixtures of the CFCs in a $\mathrm{He}$ (UHP, $99.999 \%$ ) bath gas were prepared manometrically in $12 \mathrm{~L}$ Pyrex bulbs and used to deliver the CFC sample to the UV and infrared absorption cells. Over the course of the study, multiple gas mixtures were prepared for each of the CFCs with mixing ratios ranging between 0.5 and $27 \%$. The dilute mixtures were prepared with an estimated accuracy of $\pm \sim 1 \%$. The UV and infrared spectra obtained for the CFCs were independent of the sample mixing ratio and absorption cell total pressure. Pressures were measured using calibrated capacitance manometers. Uncertainties given throughout the paper are $2 \sigma$ unless noted otherwise.

\section{Results and discussion}

The absorption spectrum, $\sigma(\lambda, T)$, measurements obeyed Beer's law with fit precisions of $\sim 1 \%$ or less for all wavelengths and temperatures included in this study. Replicate measurements using different sample mixing ratios, bath gas, range of absorption, and optical filtering agreed to within the measurement precision and were combined in a global linear least-squares fit in the final data analysis.

The UV absorption spectra of the CFC-112 and CFC-112a samples were measured at 10 discrete wavelengths between 192.5 and $235 \mathrm{~nm}$ at 5 discrete temperatures between 230 and $323 \mathrm{~K}$. The results, not corrected for the isomeric impurity present in the samples, are summarized in Tables $\mathrm{S} 1$ and S2 and shown in Figs. S1 and S2 of the Supplement. To account for the isomeric impurity, $\sigma(\lambda, T)$ for CFC-112 and CFC-112a were parameterized using the following empirical formula:

$\ln (\sigma(\lambda, T))=\sum_{i} A_{i} \lambda_{i}{ }^{i}+(T-296) \sum_{i} B_{i} \lambda_{i}{ }^{i}$.

The parameterizations reproduced the experimental data to better than $\sim 2 \%$ over the wavelength range most critical to atmospheric photolysis, i.e., between 195 and $215 \mathrm{~nm}$. The results from the ${ }^{19} \mathrm{~F}$ NMR sample analysis were then used to obtain the final spectrum parameterizations.

The UV absorption spectra for CFC-113a and CFC-114a were measured at 10 discrete wavelengths between 192.5 and $235 \mathrm{~nm}$ at 6 discrete temperatures between 207 and $323 \mathrm{~K}$. The cross section results are given in Tables 1 and 2 and shown in Figs. 1 and 2. The CFC UV absorption spectra were parameterized using Eq. (2). The parameterizations reproduced the experimental data to within $\sim 4 \%$ or better, as shown in Figs. 1 and 2.

The fit parameters are given in Table 3, and a comparison of the parameterized $296 \mathrm{~K}$ spectra is shown in Fig. 3. The UV absorption spectra of the CFCs are continuous over the wavelength range included in this study with a precipitous decrease in cross section with increasing wavelength. A decrease in $\sigma(\lambda, T)$ with decreasing temperature was observed at nearly all wavelengths included in this study with the temperature dependence being greatest at the longer wavelengths (see Figs. 1, 2, and S1 and S2). The $\sigma(\lambda, 323 \mathrm{~K}$ ) measurements, although not entirely atmospherically relevant, were included in the study to better define the absorption spectrum temperature dependence and its parameterization. As shown in Fig. 3, the UV absorption spectra for the CFCs show distinct differences in their absolute cross sections and wavelength dependence over the region most critical for determining their atmospheric photolysis rates, i.e., lifetimes. The spectra demonstrate that CFCs with increased chlorine content are stronger absorbers in this wavelength region, although the molecular structure of the molecule also plays an important role. For example, the $\mathrm{C}_{2} \mathrm{Cl}_{4} \mathrm{~F}_{2}$ isomer with more 
Table 1. $\mathrm{CCl}_{3} \mathrm{CF}_{3}$ (CFC-113a) UV absorption cross section data $\left(10^{-20} \mathrm{~cm}^{2}\right.$ molecule ${ }^{-1}$, base e) obtained in this work.

\begin{tabular}{rcccccc}
\hline$\lambda(\mathrm{nm})$ & $323 \mathrm{~K}$ & $296 \mathrm{~K}$ & $271 \mathrm{~K}$ & $250 \mathrm{~K}$ & $232 \mathrm{~K}$ & $207 \mathrm{~K}$ \\
\hline 192.5 & $131.6 \pm 1.5$ & $132.5 \pm 1.1$ & $136.9 \pm 1.0$ & $137.2 \pm 0.9$ & $141.4 \pm 1.6$ & $139.7 \pm 0.9$ \\
195 & $103.9 \pm 0.2$ & $106.6 \pm 0.6$ & $106.8 \pm 0.9$ & $107.5 \pm 1.2$ & $110.2 \pm 1.0$ & $111.0 \pm 0.3$ \\
200 & $64.3 \pm 0.2$ & $63.9 \pm 0.6$ & $63.9 \pm 1.2$ & $63.6 \pm 0.6$ & $64.5 \pm 0.6$ & $63.5 \pm 0.4$ \\
205 & $35.3 \pm 0.14$ & $34.1 \pm 0.2$ & $33.5 \pm 0.13$ & $33.2 \pm 0.2$ & $31.9 \pm 0.3$ & $31.3 \pm 0.3$ \\
210 & $17.3 \pm 0.10$ & $16.2 \pm 0.1$ & $15.3 \pm 0.1$ & $14.4 \pm 0.1$ & $13.9 \pm 0.17$ & $12.5 \pm 0.2$ \\
215 & $7.99 \pm 0.02$ & $7.25 \pm 0.01$ & $6.58 \pm 0.02$ & $5.94 \pm 0.06$ & $5.77 \pm 0.06$ & $5.26 \pm 0.07$ \\
220 & $3.57 \pm 0.014$ & $3.07 \pm 0.02$ & $2.65 \pm 0.007$ & $2.36 \pm 0.02$ & $2.23 \pm 0.008$ & $2.09 \pm 0.02$ \\
225 & $1.55 \pm 0.014$ & $1.29 \pm 0.01$ & $1.04 \pm 0.004$ & $0.912 \pm 0.006$ & $0.813 \pm 0.01$ & $0.778 \pm 0.04$ \\
230 & $0.673 \pm 0.009$ & $0.521 \pm 0.004$ & $0.418 \pm 0.003$ & $0.357 \pm 0.008$ & $0.322 \pm 0.003$ & \\
235 & $0.297 \pm 0.018$ & $0.208 \pm 0.001$ & $0.157 \pm 0.006$ & $0.139 \pm 0.006$ & & \\
\hline
\end{tabular}

* Quoted uncertainties are $2 \sigma$ fit precision values (rounded off).

Table 2. $\mathrm{CCl}_{2} \mathrm{FCF}_{3}(\mathrm{CFC}-114 \mathrm{a}) \mathrm{UV}$ absorption cross section data $\left(10^{-20} \mathrm{~cm}^{2}\right.$ molecule ${ }^{-1}$, base e) obtained in this work.

\begin{tabular}{rcccccc}
\hline$\lambda(\mathrm{nm})$ & $323 \mathrm{~K}$ & $296 \mathrm{~K}$ & $271 \mathrm{~K}$ & $250 \mathrm{~K}$ & $232 \mathrm{~K}$ & $207 \mathrm{~K}$ \\
\hline 192.5 & $32.8 \pm 0.2$ & $32.2 \pm 0.3$ & $31.6 \pm 0.2$ & $30.7 \pm 0.2$ & $30.0 \pm 0.3$ & $28.2 \pm 0.2$ \\
195 & $21.8 \pm 0.1$ & $20.7 \pm 0.1$ & $19.9 \pm 0.1$ & $19.0 \pm 0.1$ & $18.4 \pm 0.1$ & $17.3 \pm 0.1$ \\
200 & $8.72 \pm 0.01$ & $7.86 \pm 0.045$ & $7.26 \pm 0.02$ & $6.70 \pm 0.03$ & $6.26 \pm 0.04$ & $5.88 \pm 0.05$ \\
205 & $3.31 \pm 0.01$ & $2.86 \pm 0.01$ & $2.50 \pm 0.03$ & $2.29 \pm 0.02$ & $2.12 \pm 0.02$ & $1.91 \pm 0.02$ \\
210 & $1.21 \pm 0.003$ & $0.991 \pm 0.003$ & $0.835 \pm 0.006$ & $0.757 \pm 0.006$ & $0.655 \pm 0.083$ & $0.555 \pm 0.002$ \\
215 & $0.440 \pm 0.002$ & $0.345 \pm 0.001$ & $0.276 \pm 0.001$ & $0.246 \pm 0.006$ & $0.197 \pm 0.001$ & $0.168 \pm 0.001$ \\
220 & $0.162 \pm 0.002$ & $0.118 \pm 0.0004$ & $0.0926 \pm 0.0003$ & $0.0786 \pm 0.0013$ & $0.0626 \pm 0.0003$ & $0.0534 \pm 0.0014$ \\
225 & $0.0600 \pm 0.001$ & $0.0409 \pm 0.0006$ & $0.0307 \pm 0.0002$ & $0.0253 \pm 0.0002$ & $0.0204 \pm 0.0004$ & $0.0176 \pm 0.0046$ \\
230 & & $0.0147 \pm 0.0004$ & $0.0110 \pm 0.0002$ & & & \\
235 & & $0.00553 \pm 0.00025$ & & & & \\
\hline
\end{tabular}

* Quoted uncertainties are $2 \sigma$ fit precision values (rounded off)

chlorine atoms on a carbon atom, $\mathrm{CFC}-112 \mathrm{a}\left(\mathrm{CCl}_{3} \mathrm{CClF}_{2}\right)$, absorbs more strongly than $\mathrm{CFC}-112\left(\mathrm{CCl}_{2} \mathrm{FCCl}_{2} \mathrm{~F}\right)$.

The spectrum parameterizations given in Table 3 reproduce the experimental data very well. The overall $2 \sigma$ uncertainty in $\sigma(\lambda, T)$ for CFC-112, CFC-112a, CFC-113, and CFC-114a, including estimated systematic errors, is estimated to be $\sim 4 \%$ over the range of wavelengths and temperatures included in this study.

The measured infrared spectra for each of the CFCs obeyed Beer's law with a fit precision of $\sim 0.3 \%$ and were independent of total pressure over the pressure range 20250 Torr (He bath gas). The infrared spectra are shown in Fig. 4, and digitized spectra are available in the Supplement. Table S3 in the Supplement provides a detailed comparison of our results with those of Olliff and Fischer (1992, 1994) for all the CFCs and Etminan et al. (2014) for CFC113a. Overall the agreement between the studies is better than $10 \%$.

\section{Atmospheric implications}

The atmospheric loss processes, lifetimes, ODPs, and associated uncertainties for the CFCs included in this study were quantified using the Goddard Space Flight Center (GSFC) 2-D atmospheric model (Fleming et al., 2011). The calculations used the UV spectrum parameterizations obtained in this work with an assumed unit photolysis quantum yield at all wavelengths. As discussed in Sect. 3, an overall $2 \sigma$ uncertainty of $4 \%$ was used at all wavelengths and temperatures for the UV cross sections of the four CFCs. For Lyman- $\alpha$ $(121.567 \mathrm{~nm})$, absorption cross sections are not available for these CFCs; values (in units of $10^{-17} \mathrm{~cm}^{2}$ molecule ${ }^{-1}$ ) of 13 , $15,9.8$, and 2 were estimated for CFC-112, CFC-112a, CFC113a, and CFC-114a, respectively, based on values available for similar molecules (see Ko et al., 2013, chap. 3). An estimated Lyman- $\alpha$ cross section uncertainty factor of $2(2 \sigma)$ was used. Rate coefficients for the $\mathrm{O}\left({ }^{1} \mathrm{D}\right)$ reaction with CFC-113a and CFC-114a were taken from Baasandorj et al. (2011) with $2 \sigma$ uncertainty factors of 1.25 and 1.2, respectively (Burkholder et al., 2015b). Rate coefficients for the $\mathrm{O}\left({ }^{1} \mathrm{D}\right)$ reaction with $\mathrm{CFC}-112$ and $\mathrm{CFC}-112$ a were estimated to be $3 \times 10^{-10} \mathrm{~cm}^{3}$ molecule ${ }^{-1} \mathrm{~s}^{-1}$ with a 0.9 reac- 
Table 3. Parameterization of the UV absorption spectra for $\mathrm{CCl}_{2} \mathrm{FCCl}_{2} \mathrm{~F}(\mathrm{CFC}-112), \mathrm{CCl}_{3} \mathrm{CClF}_{2}(\mathrm{CFC}-112 \mathrm{a}), \mathrm{CCl}{ }_{3} \mathrm{CF} 3(\mathrm{CFC}-113 \mathrm{a})$, and $\mathrm{CCl}_{2} \mathrm{FCF}_{3}$ (CFC-114a) obtained in this work. The parameterization is for wavelengths $192.5-235 \mathrm{~nm}$ and temperatures $230-323 \mathrm{~K}$ for $\mathrm{CFC}$ 112 and CFC-112a and 207-323 K for CFC-113a and CFC-114a. Units: $\sigma(\lambda, T)\left(\mathrm{cm}^{2}\right.$ molecule ${ }^{-1}$, base e), $\lambda(\mathrm{nm})$, and $T(\mathrm{~K}) \ln (\sigma(\lambda, T))=\sum_{i} A_{i} \lambda_{i}{ }^{i}+(T-296) \sum_{i} B_{i} \lambda_{i}{ }^{i}$.

\begin{tabular}{|c|c|c|c|}
\hline Molecule & $i$ & $A_{i}$ & $B_{i}$ \\
\hline \multicolumn{4}{|c|}{$\mathrm{CCl}_{2} \mathrm{FCCl}_{2} \mathrm{~F}(\mathrm{CFC}-112)$} \\
\hline & 0 & -1488.6207 & 6.04688 \\
\hline & 1 & 18.43604 & -0.0801501 \\
\hline & 2 & -0.02897393 & 0.0001201698 \\
\hline & 3 & -0.00051504703 & $2.610366 \times 10^{-6}$ \\
\hline & 4 & $2.644261 \times 10^{-6}$ & $-1.3959106 \times 10^{-8}$ \\
\hline & 5 & $-3.7258313 \times 10^{-9}$ & $2.0719264 \times 10^{-11}$ \\
\hline \multicolumn{4}{|c|}{$\mathrm{CCl}_{3} \mathrm{CClF}_{2}(\mathrm{CFC}-112 \mathrm{a})$} \\
\hline & 0 & -560.3404 & 10.37492 \\
\hline & 1 & 9.534427 & -0.182485408 \\
\hline & 2 & -0.06987945 & 0.0011614979 \\
\hline & 3 & 0.0002657157 & $-2.9864183 \times 10^{-6}$ \\
\hline & 4 & $-5.491224 \times 10^{-7}$ & $1.547878 \times 10^{-9}$ \\
\hline & 5 & $4.993769 \times 10^{-10}$ & $3.36518 \times 10^{-12}$ \\
\hline \multicolumn{4}{|c|}{$\mathrm{CCl}_{3} \mathrm{CF}_{3}(\mathrm{CFC}-113 \mathrm{a})$} \\
\hline & 0 & -319.173 & 2.89174 \\
\hline & 1 & 2.70954 & -0.0348043 \\
\hline & 2 & 0.00457404 & $3.6233 \times 10^{-5}$ \\
\hline & 3 & -0.0001288147 & $1.08853 \times 10^{-6}$ \\
\hline & 4 & $4.71409 \times 10^{-7}$ & $-5.25744 \times 10^{-9}$ \\
\hline & 5 & $-5.35388 \times 10^{-10}$ & $7.26095 \times 10^{-12}$ \\
\hline \multicolumn{4}{|c|}{$\mathrm{CCl}_{2} \mathrm{FCF}_{3}(\mathrm{CFC}-114 \mathrm{a})$} \\
\hline & 0 & -253.6338 & 0.52031 \\
\hline & 1 & 2.899454 & -0.005044 \\
\hline & 2 & -0.0081158 & $1.6142 \times 10^{-6}$ \\
\hline & 3 & $-3.68328 \times 10^{-5}$ & $7.2259 \times 10^{-8}$ \\
\hline & 4 & $2.071842 \times 10^{-7}$ & $2.4996 \times 10^{-11}$ \\
\hline & 5 & $-2.5764 \times 10^{-10}$ & $-5.9642 \times 10^{-13}$ \\
\hline
\end{tabular}

tive branching ratio and an uncertainty factor of $1.5(2 \sigma)$. All other kinetic and photochemical parameters were taken from Sander et al. (2011). All model results presented in this study are for year 2010 steady-state conditions. Surface mixing ratio boundary conditions for 2010 are based on the Laube et al. (2014) results for CFC-112, CFC-112a, and CFC-113a; for CFC-114a, a 2010 value of $1.6 \mathrm{ppt}$ is used, based on measurements of CFC-114, which are a combination of CFC114 and CFC-114a, with an assumed relative contribution of $10 \%$ for CFC-114a (WMO, 2014).

Model calculations of the CFC fractional atmospheric loss processes are given in Table 4, and the altitude profiles for CFC-112 are shown in Fig. 5. The calculated atmospheric profiles for CFC-112a, CFC-113a, and CFC-114a are provided in the Supplement. UV photolysis is the predominant atmospheric loss process for each of the CFCs. Lyman- $\alpha$ photolysis is important only in the mesosphere above $65 \mathrm{~km}$; it has a negligible contribution to the overall global loss $(<0.001)$. The $\mathrm{O}\left({ }^{1} \mathrm{D}\right)$ reaction is a minor stratospheric loss process, $\sim 2 \%$, for CFC-112, CFC-112, and CFC-113a, but more significant for CFC-114a, $\sim 7 \%$. The UV photolysis and $\mathrm{O}\left({ }^{1} \mathrm{D}\right)$ reactive loss of the CFCs leads to the direct release of reactive chlorine and the formation of chlorine containing radicals (Burkholder et al., 2015a).

The CFC lifetimes were computed as the ratio of the annually averaged global atmospheric burden to the vertically integrated annually averaged total global loss rate (Ko et al., 2013). The total global lifetime ( $\left.\tau_{\mathrm{Tot}}\right)$ was also separated by the troposphere ( $\tau_{\text {Trop }}$, surface to the tropopause, seasonally and latitude-dependent), stratosphere $\left(\tau_{\text {Strat }}\right)$, and meso- 
Table 4. Fractional losses and ranges (in parentheses) for $\mathrm{CCl}_{2} \mathrm{FCCl}_{2} \mathrm{~F}(\mathrm{CFC}-112), \mathrm{CCl}_{3} \mathrm{CClF}_{2}(\mathrm{CFC}-112 \mathrm{a}), \mathrm{CCl}{ }_{3} \mathrm{CF} 3(\mathrm{CFC}-113 \mathrm{a})$, and $\mathrm{CCl}_{2} \mathrm{FCF}_{3}$ (CFC-114a) calculated using the GSFC 2-D model and the UV absorption spectra and estimated Lyman- $\alpha$ cross sections reported in this work.

\begin{tabular}{|c|c|c|c|}
\hline Molecule & Lyman- $\alpha$ & $190-230 \mathrm{~nm}$ & $\mathrm{O}\left({ }^{1} \mathrm{D}\right)$ \\
\hline $\begin{array}{r}\mathrm{CCl}_{2} \mathrm{FCCl}_{2} \mathrm{~F} \\
(\mathrm{CFC}-112)\end{array}$ & $<0.001$ & 0.978 (0.953-0.99) & $0.022(0.047-0.01)$ \\
\hline $\begin{array}{l}\mathrm{CCl}_{3} \mathrm{CClF}_{2} \\
\quad(\mathrm{CFC}-112 \mathrm{a})\end{array}$ & $<0.001$ & $0.979(0.955-0.99)$ & $0.021(0.045-0.01)$ \\
\hline $\begin{array}{l}\mathrm{CCl}_{3} \mathrm{CF}_{3} \\
\quad(\mathrm{CFC}-113 \mathrm{a})\end{array}$ & $<0.001$ & $0.979(0.968-0.986)$ & $0.021(0.032-0.014)$ \\
\hline $\begin{array}{l}\mathrm{CCl}_{2} \mathrm{FCF}_{3} \\
\quad(\mathrm{CFC}-114 \mathrm{a})\end{array}$ & $<0.001$ & $0.929(0.903-0.948)$ & $0.071(0.097-0.052)$ \\
\hline
\end{tabular}

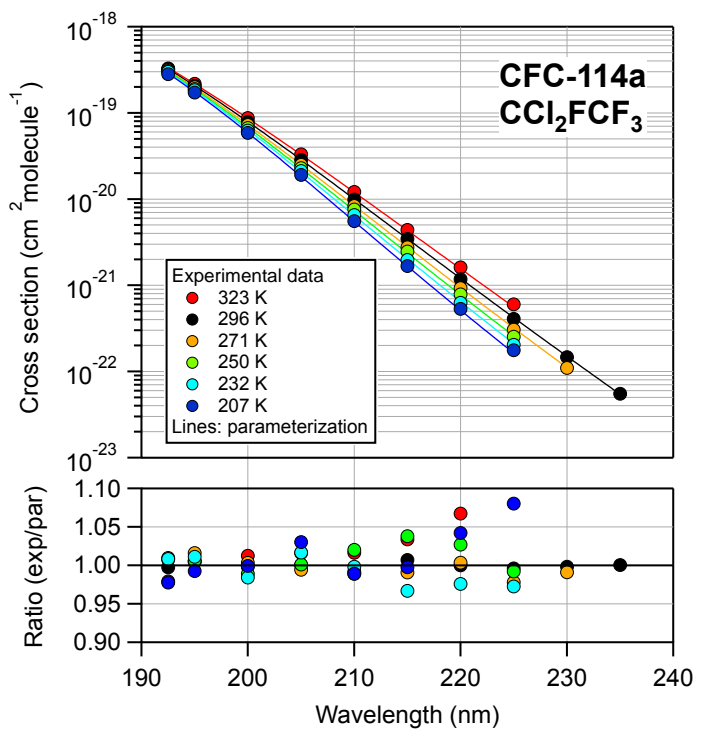

Figure 2. $\mathrm{CCl}_{2} \mathrm{FCF}_{3}$ (CFC-114a) UV absorption spectrum (base e) and parameterization obtained in this work. Cross section data (symbols, Table 2) and the parameterization of the data using the empirical formula and parameters given in Table 3 (see text). The lower frame shows the overall quality of the parameterization.

sphere $\left(\tau_{\text {Meso }},<1 \mathrm{hPa}\right)$ using the total global atmospheric burden and the loss rate integrated over the different atmospheric regions such that

$\frac{1}{\tau_{\text {Tot }}}=\frac{1}{\tau_{\text {Trop }}}+\frac{1}{\tau_{\text {Strat }}}+\frac{1}{\tau_{\text {Meso }}}$.

The 2-D model total global annually averaged lifetimes and the range in lifetimes are given in Table 5. The $2 \sigma$ range in the lifetime was calculated using the absolute $2 \sigma$ maximum and minimum in the UV absorption spectra and estimated Lyman- $\alpha$ cross sections reported in the present work, along with the $2 \sigma$ uncertainties in the $\mathrm{O}\left({ }^{1} \mathrm{D}\right)$ rate coefficients taken from Sander et al. (2011). The CFCs are long-lived and primarily removed in the stratosphere by UV photolysis. The uncertainty in the calculated lifetime due to the uncer-

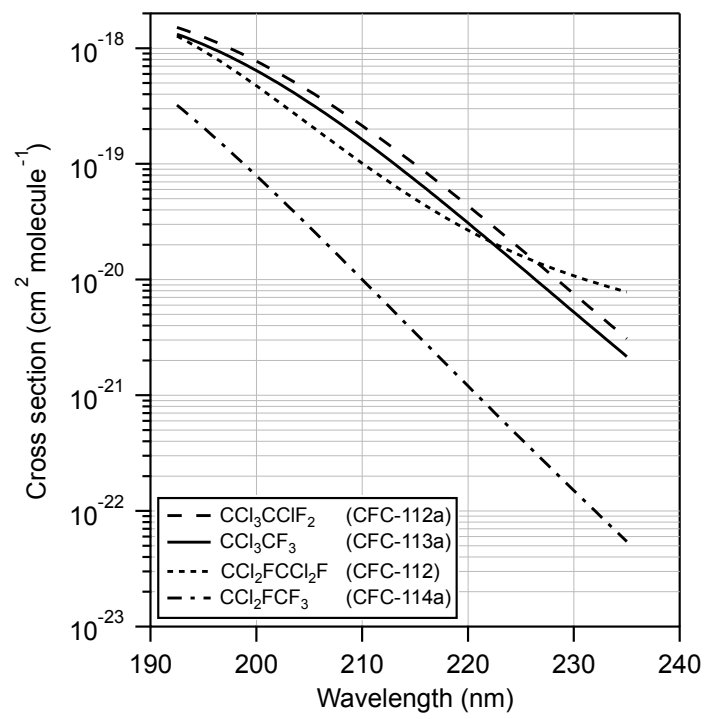

Figure 3. UV absorption spectra (base e) of CFC-112, CFC-112a, CFC-113a, and CFC-114a at $296 \mathrm{~K}$ calculated using the parameterization from this work (Table 3 ) over the wavelength range of our experimental measurements.

tainty in the UV absorption spectra measured in this work is small, $<3 \%$. The absolute lifetime uncertainty due to the kinetic and photochemical input parameters is expected to be small compared to that calculated using different atmospheric models due to the individual model treatment of dynamics, chemistry, radiation, numerics, and other processes (Chipperfield et al., 2014; Ko et al., 2013). In general, the lifetime uncertainty due to the kinetic and photochemical input parameters is also expected to be small compared to the uncertainty due to transport processes and actinic fluxes (due to, for example, uncertainty in the $\mathrm{J}\left[\mathrm{O}_{2}\right]$ cross sections; e.g., see Ko et al., 2013). However, evaluation of all processes that contribute to uncertainty in the total CFC lifetime is beyond the scope of the present paper.

The model-calculated stratospheric lifetimes for CFC-112, CFC-112a, and CFC-113a are in reasonable agreement with 
Table 5. Atmospheric lifetimes $(\tau)^{\mathrm{a}}$ and ranges ${ }^{\mathrm{b}}$ (years) for $\mathrm{CCl}_{2} \mathrm{FCCl}_{2} \mathrm{~F}(\mathrm{CFC}-112), \mathrm{CCl}_{3} \mathrm{CClF}_{2}(\mathrm{CFC}-112 \mathrm{a}), \mathrm{CCl}_{3} \mathrm{CF} 3(\mathrm{CFC}-113 \mathrm{a})$, and $\mathrm{CCl}_{2} \mathrm{FCF}_{3}$ (CFC-114a) calculated using the GSFC 2-D model and the UV absorption spectra reported in this work.

\begin{tabular}{|c|c|c|c|c|c|c|c|}
\hline \multirow[b]{2}{*}{ Molecule } & \multicolumn{2}{|c|}{ Tropospheric } & \multicolumn{2}{|c|}{ Stratospheric } & \multirow{2}{*}{$\begin{array}{r}\text { Mesospheric } \\
\tau\end{array}$} & \multicolumn{2}{|r|}{ Total } \\
\hline & $\tau$ & $\tau$ range & $\tau$ & $\tau$ range & & $\tau$ & $\tau$ range \\
\hline $\begin{array}{r}\mathrm{CCl}_{2} \mathrm{FCCl}_{2} \mathrm{~F} \\
(\mathrm{CFC}-112)\end{array}$ & 2276 & $(1718-2710)$ & 65.4 & $(64.2-66.3)$ & $>10^{6}$ & 63.6 & $(61.9-64.7)$ \\
\hline $\begin{array}{l}\mathrm{CCl}_{3} \mathrm{CClF}_{2} \\
\quad(\mathrm{CFC}-112 \mathrm{a})\end{array}$ & 1187 & (938-1371) & 53.8 & $(52.8-54.6)$ & $>10^{6}$ & 51.5 & $(50.0-52.6)$ \\
\hline $\begin{array}{l}\mathrm{CCl}_{3} \mathrm{CF}_{3} \\
\quad(\mathrm{CFC}-113 \mathrm{a})\end{array}$ & 1476 & $(1290-1645)$ & 57.5 & $(56.7-58.3)$ & $>10^{6}$ & 55.4 & $(54.3-56.3)$ \\
\hline $\begin{array}{l}\mathrm{CCl}_{2} \mathrm{FCF}_{3} \\
\quad(\mathrm{CFC}-114 \mathrm{a})\end{array}$ & 8312 & (6286-10480) & 106.7 & (104.7-108.6) & $3 \times 10^{5}$ & 105.3 & (102.9-107.4) \\
\hline
\end{tabular}

${ }^{a}$ Global annually averaged values. ${ }^{\mathrm{b}}$ calculated using $2 \sigma$ upper and lower limits of the UV absorption cross sections and estimated Lyman- $\alpha$ cross sections reported in this work (see text) and $\mathrm{O}\left({ }^{1} \mathrm{D}\right)$ rate coefficient uncertainties from Sander et al. (2011).

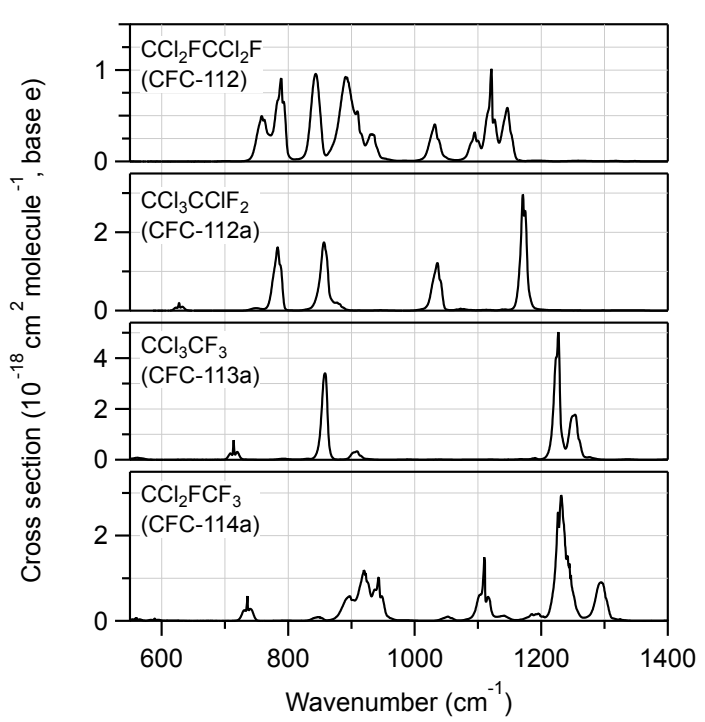

Figure 4. Infrared absorption spectra of $\mathrm{CCl}_{2} \mathrm{FCCl}_{2} \mathrm{~F}$ (CFC-112), $\mathrm{CCl}_{3} \mathrm{CClF}_{2}$ (CFC-112a), $\mathrm{CCl}_{3} \mathrm{CF}_{3}$ (CFC-113a), and $\mathrm{CCl}_{2} \mathrm{FCF}_{3}$ (CFC-114a) at $296 \mathrm{~K}$ obtained in this work.

the values of 51 (37-82), 44 (28-98), and 51 (27-264) years reported by Laube et al. (2014) (uncertainty ranges in parentheses). The lifetimes reported by Laube et al. were based on a tracer-tracer analysis (see Plumb and Ko, 1992; Volk et al., 1997, for method details) using a reference CFC-11 lifetime of 45 years. Scaling to the 52-year CFC-11 lifetime given in WMO (2014) brings the results into better agreement with the present work. The range of lifetimes obtained in the model results, which was determined solely based on the uncertainty in the kinetic and photochemical input parameters, is, however, significantly less than that obtained in the tracertracer analysis. It is worth noting that while the total global lifetimes of the isomers CFC-112 and CFC-112a are similar, the lifetimes of CFC-113a (55.4 years) and CFC-114a (105.3 years) are substantially shorter (by $\sim 60 \%$ ) than those of the isomers CFC-113 (93 years) and CFC-114 (189 years) (WMO, 2014).

\subsection{Ozone depletion potentials (ODPs)}

The semi-empirical and model-calculated ODPs for the CFCs are given in Table 6. The ODP was calculated following the methodology used previously (Fisher et al., 1990; Wuebbles, 1983). Steady-state simulations for year 2010 were run with the surface boundary conditions for the four CFCs, and CFC-11 (used as the reference compound) increased individually to obtain a $\sim 1 \%$ depletion in annually averaged global total ozone. The ODP was then taken as the change in global ozone per unit mass emission of the CFC relative to the change in global ozone per unit mass emission of CFC-11. Each of these compounds is a potent ozone-depleting substance. The model-calculated ODPs for CFC-112, CFC-112a, and CFC-113a are similar to the semiempirical values inferred by Laube et al. (2014). The range in the model ODP values due to uncertainty in the UV spectra obtained in this work and uncertainty in the $\mathrm{O}\left({ }^{1} \mathrm{D}\right)$ rate coefficient was found to be small $(< \pm 0.015)$.

Table 6 also includes ODPs for CFC-113 and CFC-114. These are larger than the ODPs for the isomers CFC-113a and CFC-114a (especially CFC-113 vs. CFC-113a), likely due in part to the longer lifetimes of CFC-113 and CFC-114. For comparison with other related compounds, the ODPs of CFC-115, CFC-12, and $\mathrm{CCl}_{4}$ are also included in Table 6 . This shows the general decrease in ODP with decreasing chlorination among CFC-112a, CFC-112, CFC-113a, CFC113, CFC-114a, CFC-114, and CFC-115. We also note that the model ODPs for CFC-112 and CFC-112a are generally similar, although slightly less than $\mathrm{CCl}_{4}$, which also contains four chlorine atoms. For most of the compounds listed in Table 6 , the model ODPs are larger than the semi-empirical values. The semi-empirical ODPs are dependent on observationally based fractional release factors for a given stratospheric 


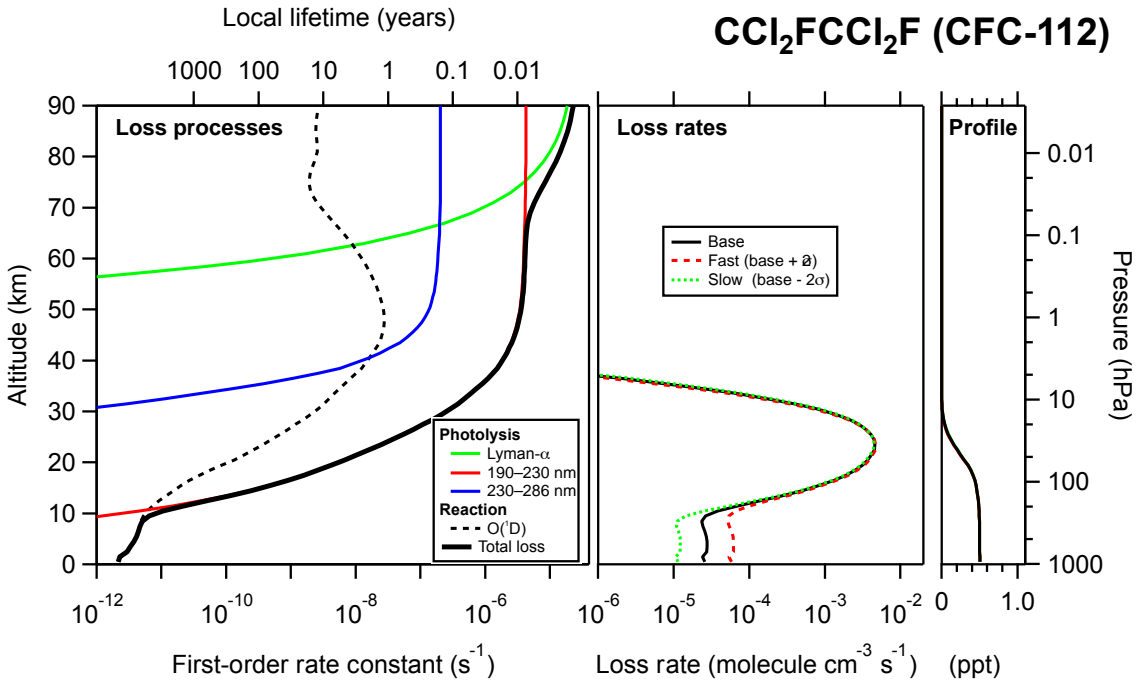

Figure 5. Global annually averaged vertical profiles of the atmospheric loss processes, molecular loss rates, and mixing ratio for $\mathrm{CCl}_{2} \mathrm{FCCl}_{2} \mathrm{~F}$ (CFC-112) calculated using the GSFC 2-D atmospheric model for year 2010. The model calculations were performed using the CFC-112 UV absorption spectrum from this work and other model input parameters taken from the literature as described in the text. The global annually averaged lifetime for CFC-112 was calculated to be 63.6 (61.9-64.7) years.

Table 6. Lifetimes, ozone depletion potentials (ODPs), radiative efficiencies (REs), and global warming potentials (GWPs) obtained in this work and literature values for comparison.

\begin{tabular}{|c|c|c|c|c|c|c|c|}
\hline \multirow[t]{2}{*}{ Molecule } & \multirow[t]{2}{*}{$\begin{array}{r}\text { Lifetime } \\
\text { (years) }\end{array}$} & \multicolumn{2}{|c|}{$\begin{array}{l}\text { Ozone depletion potential } \\
\text { (ODP) }\end{array}$} & \multirow[t]{2}{*}{$\begin{array}{l}\text { Radiative efficiency } \\
\qquad\left(\mathrm{W} \mathrm{m}^{-2} \mathrm{ppb}^{-1}\right)\end{array}$} & \multicolumn{3}{|c|}{$\begin{array}{r}\text { Global warming potential } \\
\text { time horizons (years) }\end{array}$} \\
\hline & & Semi-empirical & 2-D model ${ }^{\mathrm{d}}$ & & 20 & 100 & 500 \\
\hline $\begin{array}{r}\mathrm{CCl}_{2} \mathrm{FCCl}_{2} \mathrm{~F} \\
(\mathrm{CFC}-112)\end{array}$ & 63.6 & $0.88(0.62-1.44)^{\mathrm{a}}$ & $0.98( \pm 0.015)$ & 0.28 & 5330 & 4260 & 1530 \\
\hline $\begin{array}{l}\mathrm{CCl}_{3} \mathrm{CClF}_{2} \\
\quad(\mathrm{CFC}-112 \mathrm{a})\end{array}$ & 51.5 & $0.88(0.50-2.19)^{\mathrm{a}}$ & $0.86( \pm 0.015)$ & 0.25 & 4600 & 3330 & 1110 \\
\hline $\begin{array}{l}\mathrm{CCl}_{3} \mathrm{CF}_{3} \\
\quad(\mathrm{CFC}-113 \mathrm{a})\end{array}$ & 55.4 & $0.68(0.34-3.79)^{\mathrm{a}}$ & $0.73( \pm 0.01)$ & 0.24 & 4860 & 3650 & 1240 \\
\hline $\begin{array}{l}\mathrm{CCl}_{2} \mathrm{FCF}_{3} \\
\quad(\mathrm{CFC}-114 \mathrm{a})\end{array}$ & 105.3 & & $0.72( \pm 0.01)$ & 0.28 & 6750 & 6510 & 3000 \\
\hline $\begin{array}{r}\mathrm{CCl}_{2} \mathrm{FCClF}_{2} \\
(\mathrm{CFC}-113)\end{array}$ & $93^{\mathrm{b}}$ & $0.81-0.82^{\mathrm{b}}$ & 0.95 & $0.30^{\mathrm{b}}$ & $6490^{\mathrm{b}}$ & $5820^{\mathrm{b}}$ & \\
\hline $\begin{array}{r}\mathrm{CClF}_{2} \mathrm{CClF}_{2} \\
(\mathrm{CFC}-114)\end{array}$ & $189^{\mathrm{b}}$ & $0.50^{\mathrm{b}}$ & 0.78 & $0.31^{\mathrm{b}}$ & $7710^{\mathrm{b}}$ & $8590^{\mathrm{b}}$ & \\
\hline $\begin{array}{l}\mathrm{CClF}_{2} \mathrm{CF}_{3} \\
\quad(\mathrm{CFC}-115)\end{array}$ & $540^{\mathrm{b}}$ & $0.26^{\mathrm{b}}$ & 0.44 & $0.20^{\mathrm{b}}$ & $5860^{\mathrm{b}}$ & $7670^{\mathrm{b}}$ & \\
\hline $\begin{array}{l}\mathrm{CCl}_{2} \mathrm{~F}_{2} \\
\quad(\mathrm{CFC}-12)\end{array}$ & $102^{\mathrm{b}}$ & $0.73-0.81^{b}$ & 1.01 & $0.32^{\mathrm{b}}$ & $10800^{\mathrm{b}}$ & $10200^{\mathrm{b}}$ & \\
\hline $\mathrm{CCl}_{4}$ & $26^{b, c}$ & $0.72^{\mathrm{b}}$ & 1.06 & $0.17^{\mathrm{b}}$ & $3480^{\mathrm{b}}$ & $1730^{\mathrm{b}}$ & \\
\hline
\end{tabular}

${ }^{a}$ Semi-empirical ODPs and uncertainty ranges taken from Laube et al. (2014). ${ }^{b}$ Taken from WMO (2014). ${ }^{c} \mathrm{CCl}_{4}$ stratospheric lifetime of 44 years given in WMO (2014). ${ }^{\mathrm{d}}$ The uncertainty range in the model-calculated ODPs reported here is due to the uncertainty in the UV and Lyman- $\alpha$ (estimated) spectra obtained in this work and uncertainty in the $\mathrm{O}\left({ }^{1} \mathrm{D}\right)$ rate coefficients taken from Sander et al. (2011).

mean age of air, i.e., the fractional amount of a CFC that has been dissociated at a given point in the stratosphere (and the subsequent release of inorganic chlorine), relative to the amount of a CFC that entered at the tropopause (e.g., Daniel et al., 2007; Douglass et al., 2008; Laube et al., 2013; New- man et al., 2007; Schauffler et al., 2003). Differences in the semi-empirical vs. model ODPs in Table 6 are due, at least in part, to differences in the observationally based fractional release factors taken for mid-latitude conditions compared to the global model calculations. Differences in the ODPs may 
also arise from differences in the Ko et al. (2013) lifetimes used for the semi-empirical ODPs vs. the model lifetimes, although these lifetime differences are small.

\subsection{Calculated radiative efficiencies (REs) and global warming potentials (GWPs)}

Table 6 summarizes the radiative efficiencies (REs) for the CFCs calculated using the methods described in Hodnebrog et al. (2013) and the global warming potentials (GWPs) for the 20-, 100-, and 500-year time horizons using the lifetimes and infrared spectra from this work. The CFCs are potent greenhouse gases and radiative forcing agents due to their high REs and long atmospheric lifetimes. The GWPs for these long-lived compounds are comparable or less than those of the atmospherically most abundant CFCs. For example, the 100-year time-horizon GWPs for CFC-11 $\left(\mathrm{CCl}_{3} \mathrm{~F}\right)$, CFC-12 $\left(\mathrm{CCl}_{2} \mathrm{~F}_{2}\right)$, and $\mathrm{CFC}-113\left(\mathrm{CCl}_{2} \mathrm{FCClF}_{2}\right)$ are 4660 , 10200 , and 5820, respectively (WMO, 2014). Etminan et al. (2014) reported a RE of $0.23 \mathrm{~W} \mathrm{~m}^{-2} \mathrm{ppb}^{-1}$ for CFC-113a and a $\mathrm{GWP}_{100}$ of 3310 using a lifetime of 51 years. These values are in reasonable agreement with the present results.

\section{Conclusions}

Short-wavelength UV absorption spectra for $\mathrm{CCl}_{2} \mathrm{FCCl}_{2} \mathrm{~F}$ (CFC-112), $\mathrm{CCl}_{3} \mathrm{CClF}_{2}$ (CFC-112a), $\mathrm{CCl}_{3} \mathrm{CF}_{3}$ (CFC-113a), and $\mathrm{CCl}_{2} \mathrm{FCF}_{3}(\mathrm{CFC}-114 \mathrm{a})$ measured in this work between 192.5 and $235 \mathrm{~nm}$ and at temperatures in the range 207 to $323 \mathrm{~K}$ were combined with 2-D atmospheric model calculations to assess their atmospheric loss processes, lifetimes, and ozone depletion potentials (ODPs). Short-wavelength UV photolysis was shown to be the predominant loss process for the CFCs with global annually averaged lifetimes of 63.6, 51.5, 55.4, and 105.3 years, for CFC-112, CFC-112a, CFC-113a, and CFC-114a, respectively. The uncertainty in the model-calculated lifetimes due to the $2 \sigma$ uncertainty in the UV absorption spectra reported in this work was found to be small, $<3 \%$. These CFCs are potent ozone-depleting substances with 2-D model-calculated ODPs of 0.98, 0.86, 0.73, and 0.72 for CFC-112, CFC-112a, CFC-113a, and CFC$114 \mathrm{a}$, respectively. The uncertainty in the model calculated ODPs due to the uncertainty in the UV spectra and $\mathrm{O}\left({ }^{1} \mathrm{D}\right)$ reactive loss was small, $< \pm 0.015$. These CFCs are also potent greenhouse gases with GWPs comparable to those of the most abundant CFCs present in the atmosphere.

\section{Data availability}

Additional data and figures can be found in the Supplement.

The Supplement related to this article is available online at doi:10.5194/acp-16-8043-2016-supplement.
Acknowledgements. This work was supported in part by NOAA's Atmospheric Chemistry, Carbon Cycle, and Climate (AC4) Program and NASA's Atmospheric Composition Program. The Supplement includes digitized infrared spectra as well as additional figures, model results, and tables.

Edited by: D. Heard

\section{References}

Baasandorj, M., Feierabend, K. J., and Burkholder, J. B.: Rate coefficients and $\mathrm{ClO}$ radical yields in the reaction of $\mathrm{O}\left({ }^{1} \mathrm{D}\right)$ with $\mathrm{CClF}_{2} \mathrm{CCl}_{2} \mathrm{~F}, \mathrm{CCl}_{3} \mathrm{CF}_{3}, \mathrm{CClF}_{2} \mathrm{CClF}_{2}$, and $\mathrm{CCl}_{2} \mathrm{FCF}_{3}$, Int. J. Chem Kinet., 43, 1-9, doi:10.1002/kin.20561, 2011.

Burkholder, J. B., Cox, R. A., and Ravishankara, A. R.: Atmospheric degradation of ozone depleting substances, their substitutes, and related species, Chem. Rev., 115, 3704-3759, doi:10.1021/cr5006759, 2015a.

Burkholder, J. B., Sander, S. P., Abbatt, J., Barker, J. R., Huie, R. E., Kolb, C. E., Kurylo, M. J., Orkin, V. L., Wilmouth, D. M., and Wine, P. H.: "Chemical Kinetics and Photochemical Data for Use in Atmospheric Studies, Evaluation No. 18, JPL Publication 1510, Jet Propulsion Laboratory, Pasadena, 2015, available at: http: //jpldataeval.jpl.nasa.gov/ (last access: 23 June 2016), 2015b.

Chipperfield, M. P., Liang, Q., Strahan, S. E., Morgenstern, O., Dhomse, S. S., Abraham, N. L., Archibald, A. T., Bekki, S., Braesicke, P., Di Genova, G., Fleming, E. L., Hardiman, S. C., Iachetti, D., Jackman, C. H., Kinnison, D. E., Marchand, M., Pitari, G., Pyle, J. A., Rozanov, E., Stenke, A., and Tummon, F.: Multimodel estimates of atmospheric lifetimes of long-lived ozonedepleting substances: Present and future, J. Geophys. Res., 119, 2555-2573, doi:10.1002/2013JD021097, 2014.

Daniel, J. S., Velders, G. J. M., Douglass, A. R., Forster, P. M. D., Hauglustaine, D. A., Isaksen, I. S. A., Kuijpers, L. J. M., McCulloch, A., and Wallington, T. J.: Halocarbon scenarios, ozone depletion potentials, and global warming potentials, Chapter 8 in World Meteorological Organization: Scientific assessment of ozone depletion: 2006, Global Ozone Research and Monitoring Project - Report No. 50, Geneva, 2007.

Douglass, A. R., Stolarski, R. S., Schoeberl, M. R., Jackman, C. H., Gupta, M. L., Newman, P. A., Nielsen, J. E., and Fleming, E. L.: Relationship of loss, mean age of air and the distribution of CFCs to stratospheric circulation and implications for atmospheric lifetimes, J. Geophys. Res., 113, D14309, doi:10.1029/2007JD009575, 2008.

Etminan, M., Highwood, E. J., Laube, J. C., McPheat, R. Marston, G., Shine, K. P., and Smith, K. M.: Infrared absorption spectra, radiative efficiencies, and global warming potentials of newly-detected halogenated compounds: CFC113a, CFC-112 and HCFC-133a, Atmosphere, 5, 473-483, doi:10.3390/atmos5030473, 2014.

Fisher, D. A., Hales, C. H., Filkin, D. L., Ko, M. K. W., Sze, N. D., Connell, P. S., Wuebbles, D. J., Isaksen, I. S. A., and Stordal, F.: Model calculations of the relative effects of CFCs and their replacements on stratospheric ozone, Nature, 344, 508-512, doi:10.1038/344513a0, 1990.

Fleming, E. L., Jackman, C. H., Stolarski, R. S., and Douglass, A. R.: A model study of the impact of source gas changes on 
the stratosphere for 1850-2100, Atmos. Chem. Phys., 11, 85158541, doi:10.5194/acp-11-8515-2011, 2011.

Hodnebrog, Ø., Etminan, M., Fuglestvedt, J. S., Marston, G., Myhre, G., Nielsen, C. J., Shine, K. P., and Wallington, T. J.: Global warming potentials and radiative efficiencies of halocarbons and related compounds: A comprehensive review, Rev. Geophys., 51, 300-378, doi:10.1002/rog.20013, 2013.

Ko, M. K. W., Newman, P. A., Reimann, S., Strahan, S. E., Plumb, R. A., Stolarski, R. S., Burkholder, J. B., Mellouki, W., Engel, A., Atlas, E. L., Chipperfield, M., and Liang, Q. (Eds.): Lifetimes of Stratospheric Ozone-Depleting Substances, Their Replacements, and Related Species, chapter 3, SPARC Lifetimes Report - SPARC Report No. 6., 2013.

Laube, J. C., Keil, A., Bönisch, H., Engel, A., Röckmann, T., Volk, C. M., and Sturges, W. T.: Observation-based assessment of stratospheric fractional release, lifetimes, and ozone depletion potentials of ten important source gases, Atmos. Chem. Phys., 13, 2779-2791, doi:10.5194/acp-13-2779-2013, 2013.

Laube, J. C., Newland, M. J., Hogan, C., Brenninkmeijer, C. A. M., Fraser, P. J., Martinerie, P., Oram, D. E., Reeves, C. E., Röckmann, T., Schwander, J., Witrant, E., and Sturges, W. T.: Newly detetecd ozone-depleting substances in the atmosphere, Nat. Geosci., 7, 266-269, doi:10.1038/ngeo2109, 2014.

McGillen, M. R., Fleming, E. L., Jackman, C. H., and Burkholder, J. B.: $\mathrm{CFCl}_{3}$ (CFC-11): UV absorption spectrum temperature dependence measurements and the impact on its atmospheric lifetime and uncertainty, Geophys. Res. Lett., 40, 4772-4776, doi:10.1002/grl.50915, 2013.

Newman, P. A., Daniel, J. S., Waugh, D. W., and Nash, E. R.: A new formulation of equivalent effective stratospheric chlorine (EESC), Atmos. Chem. Phys., 7, 4537-4552, doi:10.5194/acp7-4537-2007, 2007.

Olliff, M. and Fischer, G.: Integrated band intensitities of 1,1,1-trichlorotrifluoroethane, CFC113a, and 1,1,2trichlorotrifluoroethane, CFC113, Spectrochim. Acta A, 48, 229-235, doi:10.1016/0584-8539(92)80028-u, 1992.

Olliff, M. P. and Fischer, G.: Integrated absorption intensities of haloethanes and halopropanes, Spectrochimica Acta Part a-Molecular and Biomolecular Spectroscopy, 50, 2223-2237, doi:10.1016/0584-8539(93)e0027-t, 1994.
Papadimitriou, V. C., McGillen, M. R., Fleming, E. L., Jackman, C. H., and Burkholder, J. B.: $\mathrm{NF}_{3}$ : UV absorption spectrum temperature dependence and the atmospheric and climate forcing implications, Geophys. Res. Lett., 40, 1-6, doi:10.1002/grl.50120, 2013a.

Papadimitriou, V. C., McGillen, M. R., Smith, S. C., Jubb, A. M., Portmann, R. W., Hall, B. D., Fleming, E. L., Jackman, C. H., and Burkholder, J. B.: 1,2-Dichlorohexafluoro-cyclobutane $\left(1,2-\mathrm{c}-\mathrm{C}_{4} \mathrm{~F}_{6} \mathrm{Cl}_{2}, \mathrm{R}-316 \mathrm{c}\right)$ a potent ozone depleting substance and greenhous gas: Atmospheric loss processes, lifetimes, and ozone depletion and global warming potentials for the $(E)$ and $(Z)$ stereoisomers, J. Phys. Chem. A, 117, 11049-11065, doi:10.1021/jp407823k, 2013b.

Plumb, R. A. and Ko, M. K. W.: Interrelationships between mixing ratios of long-lived stratospheric constituents, J. Geophys. Res., 97, 10140-10156, doi:10.1029/92JD00450, 1992.

Sander, S. P., Abbatt, J., Barker, J. R., Burkholder, J. B., Friedl, R. R., Golden, D. M., Huie, R. E., Kolb, C. E., Kurylo, M. J., Moortgat, G. K., Orkin, V. L., and Wine, P. H.: Chemical Kinetics and Photochemical Data for Use in Atmospheric Studies, Evaluation Number 17, available at: http://jpldataeval.jpl.nasa.gov/ (last access: 23 June 2016), 2011.

Schauffler, S. M., Atlas, E. L., Donnelly, S. G., Andrews, A., Montzka, S. A., Elkins, J. W., Hurst, D. F., Romashkin, P. A., Dutton, G. S., and Stroud, V.: Chlorine budget and partitioning during SOLVE, J. Geophys. Res., 108, 4173, doi:10.1029/2001JD002040, 2003.

Volk, C. M., Elkins, J. W., Fahey, D. W., Dutton, D. S., Gilligan, J. M., Loewenstein, M., Podolske, J. R., Chan, K. R., and Gunson, M. R.: Evaluation of source gas lifetimes from stratospheric observations, J. Geophys. Res., 102, 25543-25564, doi:10.1029/97JD02215, 1997.

WMO (World Meteorological Organization), Scientific Assessment of Ozone Depletion: 2014, Global Ozone Research and Monitoring Project-Report No. 55, Geneva, Switzerland, 416 pp., 2014.

Wuebbles, D. J.: Chlorocarbon emission scenarios: potential impact on stratospheric ozone, Geophys. Res. Lett., 88, 1433-1443, doi:10.1029/JC088iC02p01433, 1983. 